The Application of Anthropological Methods to Tribal Development in New Guinea.

Author(s): E. W. P. Chinnery

Source: The Journal of the Royal Anthropological Institute of Great Britain and Ireland, Vol. 49

(Jan. - Jun., 1919), pp. 36-41

Published by: Royal Anthropological Institute of Great Britain and Ireland

Stable URL: http://www.jstor.org/stable/2843433

Accessed: 02-03-2015 22:20 UTC

Your use of the JSTOR archive indicates your acceptance of the Terms \& Conditions of Use, available at http://www.jstor.org/page/info/about/policies/terms.jsp

JSTOR is a not-for-profit service that helps scholars, researchers, and students discover, use, and build upon a wide range of content in a trusted digital archive. We use information technology and tools to increase productivity and facilitate new forms of scholarship. For more information about JSTOR, please contact support @jstor.org. 


\title{
THE APPLICATION OF ANTHROPOLOGICAL METHODS TO TRIBAL DEVELOPMENT IN NEW GUINEA.
}

\author{
By E. W. P. Chinnery, Lieut. Australian Flying Corps, formerly \\ Acting Resident Magistrate, Delta Division, Papua.
}

His Excellency the Lieutenant-Governor of British New Guinea, J. H. P. Murray, C.M.G., makes the following observations in the concluding chapter of his book, Papua (T. Fisher Unwin, London, 1912):-

Our first duties are to prevent the recurrence of epidemics, and to put down cannibalism and savagery in general, and, if we can succeed in this, and if the natives of the settled area can be educated into habits of sustained industry, the future of the Papuan is assured, and Australia will have the credit of having shown how the civilization of the twentieth century can be introduced among people in the Stone Age, not only without injury to them, but to their lasting benefit and their permanent advance upon the road of civilization.

Papua, or, as it was formerly called, British New Guinea, is divided into a number of administrative areas, each in charge of a Resident or Assistant Resident Magistrate with Patrol Officers and a force of Armed Native Constabulary. The members of the Armed Native Constabulary are natives of Papua who are trained in military duties in Port Moresby before being attached to divisional officers. The Resident Magistrate and his staff (whom I shall call "District Officers") are stationed as a rule in the most central portion of the division where they can be in close touch with their people. Population varies, but in some of the divisions there are more than 60,000 natives under control. The system of native administration is laid down by a number of Ordinances and Departmental circular letters and the District Officers perform their duties in accordance with these.

The general policy adopted throughout the British Empire in the Government of savage and barbarous races is defined by Dr. W. H. R. Rivers (Science and the Nation, 1917) as one

to uphold the indigenous culture of the subject race except where it conflicts with the moral and social ideals of the governing people.

and in reference to this, Dr. Rivers states:-

Whatever is the degree of interference with indigenous customs involved in this policy, knowledge of the culture to be modified is absolutely necessary if changes are to be made without serious injury to the moral and material culture of the people. 
The responsibilities of Officers entrusted with the Government of native races will become greater when the colonies taken from Germany are added to the Empire. I have been in Papua since 1909, and it has been my privilege to study the native in all stages of social development. During special exploration work I have been the first white man to enter many strange communities of wild men and women, while, as a District Officer in charge of more or less settled areas, I have been able to follow the evolution of primitive cultures. This experience gave me a knowledge of the psychology of numerous tribes, and the application of such knowledge to general methods of administration enabled me to assist my people through their many stages of transition.

The customs most antagonistic to civilized standards are homicide, head-hunting, and cannibalism. In the interests of Papua and its people such practices must be abolished. His Excellency the Lieutenant-Governor of Papua, on page 363 of his work, Papua, referring to the native who learns for the first time that he must never go on any more raids, never collect any more heads, and never fight again, because the Government will protect him, states :-

- . . he is likely to feel a void in his existence, for his chief occupations will be gone, and unless something is given to him which will fill the void he and his descendants will suffer. This is the case of the Papuans.

In order to appreciate effects which may be produced by a suppression of homicide and attendant customs, let us analyse the following practices:-

1. Social Homicide.-Among many of the tribes of the Owen Stanley Range, from Mt. Obree to Mt. Chapman, a boy must pass through a ceremony of initiation before attaining the privileges of adult membership. During initiation he is secluded from women, children, and uninitiated persons, and instructed in warfare, material culture and social conduct. The initiation proceeds by stages, and at each stage the progress of the candidate is tested. When the elders are convinced that the novice has absorbed the spirit of unselfishness to such an extent that his future behaviour will promote communal welfare, he is permitted to qualify for the final stage of initiation-a ceremony investing him with the homicidal insignia. In order to qualify he must kill a man of another tribe. The investiture with the homicidal decoration gives the boy the proudest moment of his life. Seated on a throne of crossed spears, he listens. to the deeds of valour of the brave men of the tribe, and in the presence of the whole tribe receives the homicidal decoration with compliments and words of encouragement. Then he becomes an adult member, and for the first time is entitled to ask the hand of a woman in marriage.

In this case we see that the suppression of homicide not only prevents a male from becoming an adult member of his tribe but also disallows marriage. 
2. Religious Homicide (Head-hunting and Cannibalism).-Almost everywhere in Papua there is evidence of a belief in a soul that leaves the body at death and becomes a ghost. Since these ghosts are believed to influence the conditions of living people they are propitiated. The tribes of the Turama, Paibuna, Omati, Kiko and Sirebi rivers in the Gulf of Papua, not yet under Government control, offer the head of an enemy on a shrine known as "Agiba" (Man, Vol. viii, No. 12-A. C. Haddon). The Agiba is carved to represent a human figure, and as the skulls of a community are offered on one or two shrines the propitiation appears to be a communal offering to ancestors who attained greatness through their influence in earlier communal life. In Kiribari village (Paiia Inlet) I noticed pigeon-hole attachments to the walls of each cubicle in the " married men's house " containing decorated skulls of enemies.

It is believed that a man captures the soul of another by killing him, and the ghost of the dead man, by the offering of the head, becomes a slave of the tutelary ghosts of the tribe of the captor, and works with them to protect such tribe against evil influences and perpetuate the source and supply of their food.

This appears to be the most important reason for head-hunting, and I have been told by some of the most noted head-hunters of the Gulf of Papua that their food supply would fail and evil would come to them if they neglected to propitiate their ghosts.

In addition to the belief in a soul which afterwards becomes a ghost there is a belief that the essence of the soul permeates the body and attaches itself to everything with which the body comes in contact. The soul essence remains in the body at death. Every man desires to increase his own soul strength, and so we have another inducement to homicide, for, by eating the body of an enemy, it is believed that a man adds to his own strength the quality of the portion eaten. So, in the belief that like produces like, the cannibal, when it is possible, eats that portion of the body of a victim which is weak in his own, that his deficiency may be reinforced.

As a general rule the person who kills the body does not partake of it. But the reason is not clear. As a similar practice is followed when a wild boar is killed I am inclined to believe that it illustrates but another form of individual unselfishness which is so evident in primitive life.

3. Homicide generally.-In many of the tribes in the Gulf of Papua communal houses must not be occupied and canoes must not be launched until human blood has been sprinkled on them. I am informed by the natives of Kerewa tribe (Aird Delta) that Messrs. Chalmers and Tompkins of the London Mission, who were murdered by them many years ago, were victims of this custom. 
Other forms of homicide, and customs equally obnoxious to our civilized morals, are practised in New Guinea to fulfil the needs of tribal welfare, but I shall confine my paper to the above practices, since they fully illustrate the difficulty of civilizing the natives without injury to their welfare.

Having shown to what extent the welfare of some communities depends on the custom of homicide, I shall now offer suggestions to show how the practice may be abolished without injury to the people.

If homicide be an essential link binding together the social and religious fabric of a community, the suppression of homicide is likely to result in the collapse of the whole structure unless something equally capable of perpetuating tribal welfare is substituted to fill the void. What is required is a substitute that will enhance the stability of primitive institutions so that their development can proceed with the cultural development of the natives. The selection of effective substitutes involves an intensive study of the cultures of the Papuan and the modes of thought which produce actions antagonistic to Government standards. When the fundamental principles underlying these customs become revealed, officers entrusted with the administration of primitive races, by the application of such knowledge, may safely lead their people through the initial stages of transition and gradually divert their energies into channels of progress and advancement. Owing to the diversity of people and customs in Papua, each tribe must be studied independently, but since the elements of culture, as a rule, present no marked diversities, what is effective as a substitute for a custom to be suppressed in one district might be modified or elaborated to meet the problem in another district. The Manua tribe of the Yodda Valley provides an instance of this, e.g. :-

1. Social Homicide.-It was necessary for the candidates to kill a man before they could qualify for the final stage of initiation. The presence of a Government station in the vicinity of their village made it impossible for them to fulfil this condition, and so many youths found themselves unable to attain adult membership and marriage. For nearly five years they remained in a state of dissatisfaction, which retarded their progress and produced a feeling of resentment against the Government. To consider the problem, a meeting of chiefs was held, and the principles of the custom were analysed. The gathering decided that the essential thing to be proved, before a youth could enter manhood, was the possession of courage, and, as the proximity of the Government made homicide inadvisable, other methods of manifesting the quality must be considered. As a result of the discussion, candidates for initiation were permitted to qualify by killing a wild boar instead of a man. This was communicated to me, and I was invited to attend the initiation ceremony, which proceeded through its final stages, in no way hampered by the substitution of boar-killing for man-killing. 
It was also decided that as the homicidal decoration could no longer be won with honour, on account of the abolition of inter-tribal warfare, it would be withdrawn from the final qualification, though fathers, if they wished, could transfer to their sons their own decorations for bravery.

Religious Homicide of the Gulf of Papua is a variant of the methods used elsewhere in Papua to secure a perpetual supply of food. In the Northern Division, where cannibalism has been stamped out, the offerings to ghosts are made by placing articles of food on a small wooden platform (Wawa) which is erected outside each house. The ghosts, it is said, visit the Wawa at night and absorb the essence of the offering. Some tribes in the Owen Stanley Range reinforce their own soul substance by rubbing into their bodies the fat of deceased relatives as it falls from the corpses while they are lying in the sun on high platforms. Other tribes increase their soul substance by inhaling the steam from a pot of stewing plants which are known to possess the virtues of strength and long life. These and other methods could be exerted to induce the Gulf tribes to abandon cannibalism. Even the most ardent cannibal would pause if he were told, in the right way, that by eating the body of a man unfortunate enough to get killed, he would be more likely to inherit the weak qualities that resulted in the man's death than any of his virtues. Other forms of homicide may be considered in this way.

The success of these operations depends on the officer charged with the transmission of new cultures. In the first place he must be capable of winning the confidence of his people and of maintaining it for all time. Finding themselves dominated by a power superior to their own, the first feeling of the people is one of fear. I have known tribes to live for days on the mountain tops in small caves and miserable shelters of fern-covered aerial roots with no food but the leaves of shrubs to sustain them; on one occasion, the women, in their anxiety to get beyond reach of my party, discarded their babies because they hampered their progress, thus adding to my burden of responsibility seven suckling infants whose needs kept me occupied most of the day and night, since to pacify their vocal assaults and secure sleep for my party, I had to feed these voracious babies for several days with condensed milk, which they sucked from my fingers until I was able to manufacture a comforter from a piece of rubber tube and a fountain-pen filler.

The District Officer who would secure the confidence of his people must be prepared to make many departures from conventional daily life, for once the people realise that the Government is an influence for their own good, the feeling of terror will be replaced by one of trust, which is the desired relationship between a District Officer and his people and the foundation of advancement. At this moment the natives are most likely to test the worth of their District Officer by discussing the elements of their cultures with him and inviting his advice regarding those 
antagonistic to Government standards. Happy is the officer who is able to help them in the struggle for readjustment, for he achieves at once, not only the loyalty and confidence of his people, but the satisfaction of diverting their energies into channels of progress and advancement. I use the word satisfaction in its full sense, for on the success of his work depends the happiness of a District Officer. He is isolated from the comforts and pleasures of civilization, sometimes for a succession of years, and his life, one long period of hardship and danger, is devoted, every moment of the day and night, to the needs of his people. But if his policy of administration be reinforced with a knowledge of the requirements of his subjects, the results will bring contentment to the people and satisfaction to the officer and his Government. Therefore any instruction that could help him to understand the psychology of his people would make his task less difficult, and enhance his value to the Administration.

My experience in Papua has convinced me that only by developing the natives and their cultural institutions together can we hope to give them a civilization more beneficial than the primitive life from which we intend to lead them, and to facilitate the achievement of this I would suggest that the policy of administration in New Guinea be reinforced as under :-

1. The general training in anthropological subjects of all District Officers and other persons holding positions of responsibility over natives (particularly a knowledge of the factors that have stimulated progress in other primitive races).

2. The publication and circulation of all existing and subsequent records of New Guinea ethnography for the guidance of such officers.

In conclusion, I would most earnestly suggest that the status of District Officers be elevated and their general conditions improved, so that the man of the Stone Age may have by his side, to help him on his arduous road to civilization, a permanent staff of earnest, capable, and contented officers. 